\title{
GOTTFRIED BENN IZMEĐU NACIONALSOCIJALIZMA I UNUTARNJE EMIGRACIJE
}

\section{Daniela Čančar}

UDK: 821.112.2Benn, G.:329.18(430)“193/194“

Prethodno priopćenje

Sažetak: Njemački književnik Gottfried Benn (1886.-1956.) postao je 1932. godine članom Pruske akademije umjetnosti, koja je od 1933. godine djelovala pod okriljem nacističke vlasti te je i sâm podržao nacionalsocijalističku ideologiju. Godinu dana kasnije Benn uviđa svoju slijepu političku iracionalnost, a 1938. godine, slijedom sve veće odbojnosti nacista prema njegovim djelima, stavljen je na "Crnu listu” i kažnjen zabranom pisanja. U svojim poslijeratnim esejima i javnim govorima Benn obrazlaže motive zbog kojih je stao na stranu nacionalsocijalista, ali iznosi i svoje razočaranje u njihove ideale, koji su se pretvorili u užas i strah od nacističke diktature. Gottfried Benn, za razliku od mnogih njemačkih pisaca i intelektualaca koji su se protivili režimu i emigrirali, ne odlazi u izgnanstvo, nego uz zabranu pisanja i objavljivanja ostaje u Trećem Reichu, potpuno se povlači iz političkog angažmana i bira takozvanu „unutarnju emigraciju”. Odabrani eseji i govori, u kojima Benn iznosi osobne stavove prema vladajućem poretku uoči i tijekom Drugog svjetskog rata, predmet su istraživanja ovoga rada.

Ključne riječi: Gottfried Benn, književnost „unutarnje emigracije”, književnost Trećeg Reicha, Drugi svjetski rat

[? [nutarnja emigracija” odraz je duhovnog stanja brojnih njemačkih književnika, 99 umjetnika i intelektualaca koji su nakon 1933. godine - po dolasku Hitlera i nacionalsocijalista na vlast - odabrali „duhovnu” emigraciju i nisu napustili Njemačku. U „duhovnoj” emigraciji živjeli su i oni koji su iz političkih, vjerskih ili nacionalnih razloga bili prisiljeni poći u izgnanstvo, gdje su se borili s jezičnim barijerama i patili zbog izolacije od svoje njemačke publike. Za vrijeme Hitlerove diktature česte su bile kazne u vidu zabrane pisanja i objavljivanja djela za književnike koji nisu napustili domovinu i nisu bili naklonjeni nacističkom režimu. ${ }^{1}$ Povlačenje u „unutarnju emigraciju” za književnike

Usp. Barbara BAUMANN - Birgitta OBERLE, Deutsche Literatur in Epochen, München 1995., 226. 
znači udaljavanje iz političkog i duhovnog svijeta vladajućeg nacionalsocijalizma, ali ne i otpor istome. $^{2}$

Promjene na kulturnoj sceni počinju dolaskom Hitlera na vlast i sve snažnijim uplitanjem propagandističke politike Pruske akademije umjetnosti u kulturni život i književno stvaralaštvo. Nakon što su 1933. godine, zbog zaoštravanja konflikta, književnici Heinrich Mann i Käthe Kollwitz istupili iz Pruske akademije umjetnosti, Gottfried Benn je preuzeo vodstvo Sekcije za pjesništvo i od članova zatražio priklanjanje principima nacionalsocijalizma. Veliki dio članova nije slijedio poziv i mnogi su protestirajući napustili akademiju (Thomas Mann, Alfred Döblin, Ricarda Huch i Jakob Wassermann). U svibnju 1933. godine iz Pruske akademije umjetnosti isključeni su svi članovi židovskog porijekla, a njihova mjesta odmah su popunjena književnicima odanim nacističkom režimu.

Uslijedile su - 10. svibnja 1933. - akcije spaljivanja knjiga velikog broja židovskih i politički nepodobnih stvaralaca, a sredinom mjeseca objavljena je i prva službena „Crna lista” s imenima preko stotinu autora, koja je za cilj prvobitno imala čišćenje javnih biblioteka od takozvanog „nenjemačkog štiva” (marksističkih i židovskih knjiga), a kasnije i zabranu objavljivanja za izdavačke kuće. U narednom periodu različiti gremiji pod kontrolom Goebbelsovog Ministarstva propagande i javnog prosvjećivanja sastavljali su specijalne liste i time neprestano povećavali broj zabranjenih knjiga, što je nacistička vlada i ozakonila izdavanjem Naredbe o štetnom i nepoželjnom štivu.

Godina 1933. označila je pogubnu promjenu za kulturni i literarni život, a dolazak Hitlera na vlast duboko se urezao u život i djelo brojnih autora koje je njegov režim proganjao iz političkih i/ili rasnih razloga. Neposredno nakon što je Hitler preuzeo vlast, a najkasnije nakon paljenja Reichstaga u veljači iste godine, mnogi autori napustili su Njemačku. Na listama s imenima velikog broja pisaca, umjetnika i znanstvenika kojima je kasnije i formalno oduzeto državljanstvo, našla su se imena Heinricha i Thomasa Manna, Bertolta Brechta i drugih, a ukupno je iz Trećeg Reicha prognano preko pet tisuća intelektualaca. Borci za bolju Njemačku, koji su ostali u zemlji, ušutkani su na mnogo radikalniji način. Već na samom početku mnogi su odvedeni u koncentracijske logore i gestapovske podrume, u kojima je veliki broj njih ubijen na zvjerski način.

Za razliku od onih autora koji su se priklonili nacionalsocijalističkom režimu i stvarali u duhu njihovih ideja, autori „unutarnje emigracije” distancirali su se na različite načine od službeno propagirane kulturne ideologije. Za većinu tih autora javna kritika vladajuće ideologije bila je nezamisliva, čak i pogubna, te je način na koji su se ogradili od nacističke ideologije više bio vidljiv na tematskoj i stilskoj razini njihovih djela, koja su se po tome razlikovala od službeno nametnutih normi nacionalsocijalističke literature. Kako bi izrazili svoj tihi otpor totalitarnoj državi, književnici se služe figurativnim kodiranjem povijesnih činjenica, pa tako, kao što ističe književni teoretičar Bernhard Zimmermann, upravo patnja, pasivnost i povlačenje postaju osnova umjetničke sublimacije, poetskog protusvijeta koji se stoički odvaja od stvarnosti. ${ }^{3}$ Kako bi izbjegli zabranu objavljivanja mnogi autori svoja djela objavljuju pod pseudonimima ili u inozemstvu, a neki su, zahvaljujući propustima nacionalsocijalističke cenzure, uspjeli objavljivati i u domaćim novinama i časopisima.

Usp. Paul RIEGEL - Wolfgang VAN RINSUM, Deutsche Literaturgeschichte. Band X. Drittes Reich und Exil 19331945, München 2000., 48.-49.

3 Usp. Bernhard ZIMMERMANN, „NS-Literatur, Exil und Innere Emigration”, Deutsche Literaturgeschichte. 20. Jahrhundert, (ur. Georg Bollenbeck, Bernhard Zimmermann, Otto F. Riewoldt i Knut Hickethier), Düsseldorf 1984., 58. 
Kakvi su kulturnopolitički paradoksi bili mogući prvih mjeseci Trećeg Reicha svjedoči i književnik Oskar Maria Graf u javnom apelu od 15. svibnja 1933. godine, u kojem govori o zastrašujućem iznenađenju kada je u dnevnom listu Berliner Börsencourir pročitao da se njegovo ime nalazi na tzv. „Bijeloj listi” autora nove Njemačke i da su njegova djela uglavnom preporučena za čitanje. Graf svoje negodovanje izražava sljedećim riječima: „Nakon cijelog mog života i nakon svega što sam napisao imam pravo zahtijevati da moje knjige budu spaljene u plamenu lomače kako ne bi dospjele u krvave ruke i bolesne mozgove smeđih ubilačkih bandi." Sličan stav imali su i brojni drugi pisci kada je u pitanju cenzura njihovih djela. Jer ne biti na listi onih koje je zabranila nacionalsocijalistička diktatura, značilo je biti podoban, a pisci koji nisu željeli sudjelovati u ostvarenjima novog režima, nisu htjeli čuti ni pozitivne kritike. Zapravo, svaka vrsta pozitivne režimske recepcije za njih je bila uvreda.

Putem „unutarnje emigracije” pošao je i njemački pisac, pjesnik, dramatičar, pripovjedač i esejist Gottfried Benn, jedan od najznačajnijih, ali zbog svog kratkog političkog djelovanja i jedan od najkontroverznijih predstavnika ekspresionizma u Njemačkoj. Kao vojni liječnik sudjelovao je u oba svjetska rata i do kraja života je radio kao liječnik u Berlinu. Dobitnik je brojnih nagrada za književnost.

Dolazak nacionalsocijalista na vlast 1933. godine Benn je pozdravio kao početak novog doba. Bennov svjetonazor donekle je imao sličnosti s nacionalsocijalističkim poimanjem povijesti i idejama o selekciji, zbog čega su ga komunisti često kritizirali kao antisocijalnog estetičara, ali i zbog kojeg je u osvit nacionalsocijalizma dijelio oduševljenje s mnogim suvremenicima i koji ga je obilježio kao simpatizera nacionalsocijalizma. ${ }^{5} \mathrm{Na}$ berlinskom radiju Benn 24. travnja 1933. čita govor Der neue Staat und die Intellektuellen (Nova država i intelektualci), u kojem slavi totalitarnu državu te istovremeno proklinje demokraciju, liberalizam i marksizam. ${ }^{6}$ U eseju Züchtung I (Uzgoj I), napisanom 1933. godine, Benn iznosi nekoliko stavova koji nedvojbeno sliče parolama nacionalsocijalista. Politička zbivanja u tadašnjoj Njemačkoj doživljava kao povijesnu transformaciju nesagledivih razmjera, a bit transformacije nastanak je totalitarne države: „Totalitarna država, za razliku od pluralističke iz protekle epohe, (...) nastupa s obilježjem potpunog identiteta duha i moći, individualnosti i kolektivnosti, slobode i nužnosti, ona je monistička, anti-dijalektička, trajna i autoritarna." ${ }^{\prime}$ Kao posebnu novost povijesne transformacije ističe razvoj - prema vlastitim riječima - specifičnog poimanja Führera, koji za njega nije oličenje moći niti je zamišljen kao načelo terora, već kao najviši duhovni princip. Führera shvaća kao stvaralački princip i odraz povijesne volje. Benn pojašnjava kako se Führeru nakon desetogodišnje javne borbe predala i masa te da ništa nije moglo spriječiti njihovo zajedničko osvajanje Trećeg Reicha. A kao krajnji rezultat povijesnih promjena, u Europi će - napola mutacijom, a napola odgojem - nastati novi čovjek: njemački čovjek. Prema Bennovim riječima njemački čovjek ni protiv koga se neće pobuniti, ali će se uzdići iznad zapadnog i istočnog tipa čovjeka. ${ }^{8}$ Sigurno je da su brojni kritičari ovdje vidjeli obilježja rasne ideologije na kojoj će nekoliko

Citirano iz napisa književnika Oscara Marije Grafa objavljenog 15. svibnja 1933. u novinama Volksstimme prema B. ZIMMERMANN, $n . d j .$, 47. (Sve citate s njemačkog na hrvatski jezik prevela D. Č.)

Usp. P. RIEGEL - W. VAN RINSUM, $n$. dj., 55.-56.

6 Usp. Gottfried BENN, „Der neue Staat und die Intellektuellen”, Gesammelte Werke in vier Bänden. Band I. Essays, Reden, Vorträge, (ur. Dieter Wellershoff), Stuttgart 1993., 440.-449. Ovdje 440. i dalje.

7 Gottfried BENN, „Züchtung I”, Gesammelte Werke in vier Bänden. Band I. Essays, Reden, Vorträge, 214.-222. Ovdje 214.

$8 \quad$ Isto, 216. 
godina kasnije počivati sramota pogubnog uspjeha nove vlasti. Drugi pak kritičari tvrde da Benn nije bio dovoljno upućen u politički program i da zbog toga nije mogao znati krajnje ciljeve nacističke diktature u Njemačkoj.

Zaslijepljenost novim političkim idejama trajala je više od godine dana, a onda u pismu od 24. kolovoza 1934. godine upućenom književnici Ini Seidel ${ }^{9}$ Benn osviješteno progovora o užasu nacističkog režima:

Živim stisnutih zubi, iznutra i izvana. Više ne mogu dalje. Određene stvari zadale su mi posljednji udarac. Jezovita tragedija! (...) Tako značajno je počelo, a tako gnusno danas izgleda. ${ }^{10}$

Bennova, kako je mnogi kritičari nazivaju, neoprostiva zabluda ili čak izdaja počela je 30. siječnja 1933. godine, a sastojala se u tome što je Benn vlastitom voljom odlučio javno stati na stranu nove vlasti i to ne samo kao tihi simpatizer nego riječima i djelima, što se očituje kroz njegovo djelovanje u Pruskoj akademiji umjetnosti, a potom u radijskim nastupima, javnim govorima i esejima. Polemika oko Bennovog političkog stava otvorena je - kao što je prethodno navedeno - 24. travnja 1933. godine kada je na radiju čitao esej o odnosu između nove države i intelektualaca, a zahuktala se mjesec dana kasnije, kada, ponovno na radiju, objavljuje govor Antwort an die literarischen Emigranten (Odgovor književnim emigrantima), javno uzvraćanje na pismo koje mu je Klaus Mann uputio iz francuskog egzila. U svom odgovoru Benn reagira na Mannovu oštru kritiku i na pitanje kako je svoje ime, koje je bilo sinonim za najvišu razinu intelektualne kulture i gotovo fanatičnu neokaljanost, mogao staviti na raspolaganje onima kojima cijela Europa upravo taj status osporava. Benn se jednakom oštrinom brani od kritika onih koji povijesne promjene promatraju kao izbjeglice u francuskim toplicama. Međutim, i ovdje Benn naglašava da emigranti propuštaju priliku biti dio povijesne transformacije i stvaranja novog biološkog tipa bijele rase. Kao opravdanje za svoj pozitivni odnos prema novom političkom režimu Benn iznosi i vlastita iskustva liječnika u radu s velikim brojem pacijenata. Od njih neprestano sluša kako im je novi državni poredak donio bolje životne uvjete. Posebno ističe radnike, koji su dobili znatno više prava nego u prethodnom razdoblju. Benn u ovom odgovoru jasno staje na stranu novog političkog režima:

(...) osobno sam potpuno opredijeljen za novu državu, jer je to moj narod koji si ovdje krči svoj put. (...) Za mene narod znači mnogo! Moju duhovnu i materijalnu egzistenciju, moj jezik, moj život, moje međuljudske odnose, ukupnu cjelinu mog duha u prvoj liniji zahvaljujem ovom narodu. ${ }^{11}$

A upravo to je razlog zašto je svoje ime stavio na raspolaganje onima za koje Klaus Mann smatra da su na najnižoj razini. Drugi je razlog za Benna to što iza novog političkog pokreta ujedinjen stoji cijeli narod. U kontekstu Bennovog govora Antwort an die literarischen Emi-

\footnotetext{
Ina Seidel (1885.-1974.) njemačka je književnica koja je u početku Drugoga svjetskog rata pisala ratnu poeziju domoljubnog karaktera, a za koju je prepoznatljivo korištenje nacističkih fraza. Autorica je kontroverznih stihova povodom 50. rođendana Adolfa Hitlera, koji je njeno ime osobno uvrstio na poseban popis među šest najznačajnijih pisaca. Neki kritičari tvrde kako je od samog početka bila žrtva nacističke ideologije moći, o čemu se i sama na sličan način očitovala još tijekom rata, ali i u djelima nastalim nakon rata.

10 Citirano iz Bennova pisma Ini Seidel prema P. RIEGEL - W. VAN RINSUM, $n$. dj., 56.

11 Gottfried BENN, „Antwort an die literarischen Emigranten”, Gesammelte Werke in vier Bänden. Band IV. Autobiographische und vermischte Schriften, (ur. Dieter Wellershoff), Stuttgart 1995., 239.-248. Ovdje 245.-246.
} 
granten mora se istaći da Benn i ovdje naglašava svoju političku neutralnost, time što pojašnjava kako nije član Hitlerove partije niti je u bliskim vezama s njezinim partijskim vođama.

Bennova fatalna politička zabluda trajala je do 30. lipnja 1934. godine kada je u „Noći dugih noževa", tijekom pobune koju je izrežirao Hitler sa svojim najbližim suradnicima, s ciljem likvidacije bivšeg oficira Ernsta Röhma, ubijeno gotovo dvije stotine zagovornika socijalne revolucije bez službene presude. Svakako da su se kod Benna već i ranije pojavile sumnje, ali navedeni događaj zadao mu je posljednji udarac, kao što i sâm bilježi u već spomenutom pismu Ini Seidel. Nakon tog događaja više nije gajio iluziju o ostvarenju povijesne transformacije države. Kao izlaz iz političke, ali i osobne zablude, za njega u obzir nije dolazio tada još mogući bijeg u inozemstvo, „gdje bi ga dočekali s podsmijehom i zluradošću”. ${ }^{12}$ Nakon Bennovog povlačenja iz javnog života kritičari su raspravljali o brojnim pitanjima: Kako se diviti nekome tko nosi teret tako neshvatljive pogreške? Kako i dalje duhovno i estetski biti fasciniran čovjekom koji se dao zavarati jezovitom prazninom duha Hitlerovog režima i kako je takav režim mogao opčiniti ličnost poput Benna? ${ }^{13}$ Slična pitanja posebno se otvaraju u usporedbi s činjenicom da je još godine 1929. njemački pisac Max HermannNeiße veličao Benna kao primjer neovisnog i superiornog svjetskog pjesnika, koji je stajao visoko iznad običnih liferanata propagandnih političkih materijala. ${ }^{14}$ Walter Lennig, autor monografije o Gottfriedu Bennu, smatra kako se tu više radi o Bennovoj zabludi u vezi sa samim sobom nego nacionalsocijalizmom i tvrdi da je Bennu ideologija nacionalsocijalizma bila gotovo nepoznata. Benn nije poznavao program Hitlerove stranke ni Mein Kampf, nije poznavao vodeće ličnosti i nikada nije bio na političkim skupovima pa zbog toga Lennig njegovu reakciju tumači tek kao odraz raspoloženja i emocija i kao posljedicu neupućenosti u politička zbivanja. Benn je, prema Lennigovim riječima, sve do 1933. i ponovno godinu dana kasnije osjećao istinsku odbojnost prema svemu političkom..$^{15}$ Književni teoretičar Bruno Hillebrand također napominje da Benn nije bio dovoljno informiran o ciljevima politike novih moćnika te da je njegova pogreška bila u tome što je vjerovao u duhovnu obnovu nacije i što je isprva ignorirao brutalne metode novog režima. ${ }^{16}$ Nešto drugačiji stav prema Bennovu političkom angažmanu zastupa književni povjesničar Peter J. Brenner:

Jedini njemački autor europske razine koji je 1933. bezrezervno stao na stranu nacionalsocijalista, bio je - pored filozofa Martina Heideggera - Gottfried Benn. U nekoliko eseja, a posebno u radijskom govoru Nova država i intelektualci i u svom nečasnom Odgovoru književnim emigrantima, usmjerenom protiv Klausa Manna, odobravao je nacionalsocijalističku ideologiju, uključujući i njezine rasističke komponente. ${ }^{17}$

Wolfgang Emmerich, biograf Gottfrieda Benna, opravdanje za Bennovo priklanjanje nacističkom režimu nalazi u njegovom nesigurnom socijalnom i ekonomskom statusu te smatra da je pjesnik u novom državnom poretku vidio mogućnost kako osigurati svoju do tada uvijek ugroženu egzistenciju, a djelovanje pod okriljem Pruske akademije umjetnosti kao izlaz iz položaja autsajdera. Ideologiju fašizma Benn doživljava kao estetizaciju politike. Nacistički režim na ulicama je na zapanjujući način postigao ono za čime je Benn žu-

\footnotetext{
Walter LENNIG, Gottfried Benn mit Selbstzeugnissen und Bilddokumenten, Reinbek bei Hamburg 1994., 111.

Isto, 114 .

Usp. Wolfgang EMMERICH, Gottfried Benn, Reinbek bei Hamburg 2006., 77.

Usp. W. LENNIG, $n$. $d j$., 114.-116.

Usp. Bruno HILLEBRAND, Benn, Frankfurt/Main 1986., 281.

Peter J. BRENNER, Neue deutsche Literaturgeschichte. Vom „Ackermann” zu Günter Grass, Tübingen 2004., 259.
} 


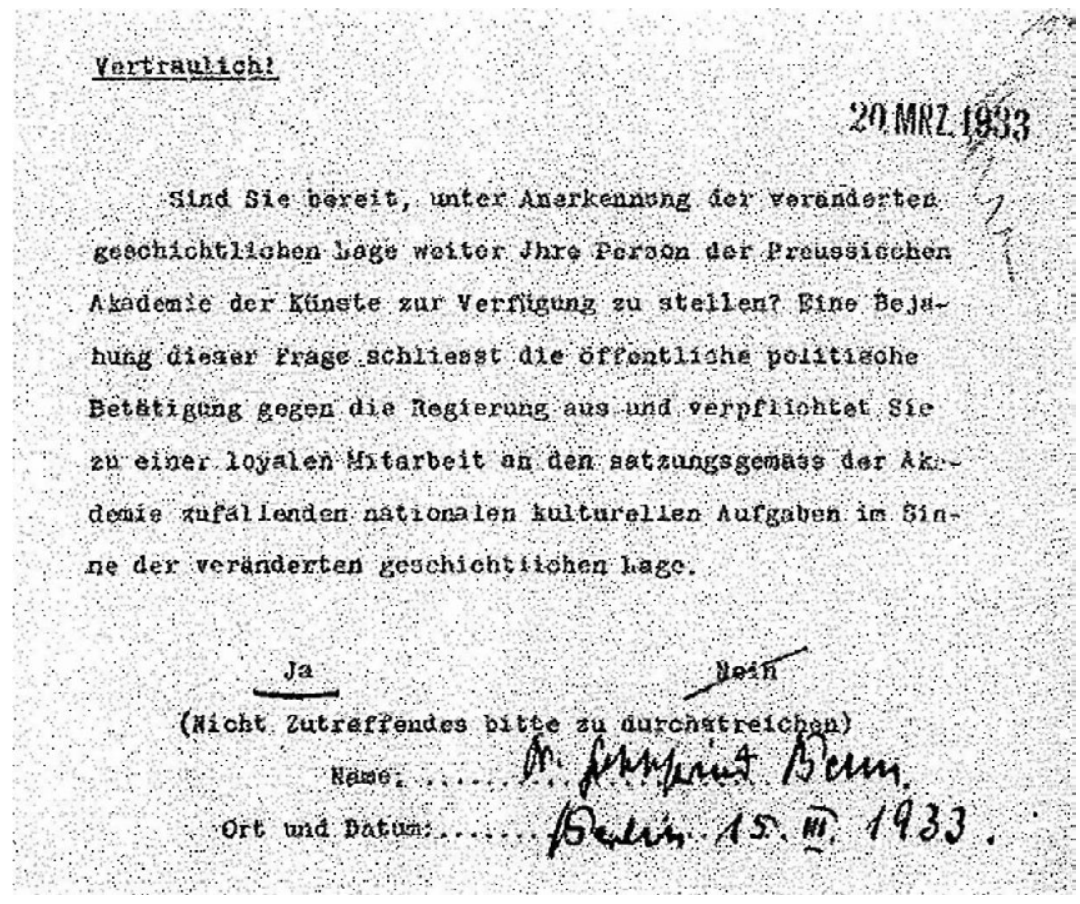

Slika 1. Dokument kojim se Gottfried Benn obvezao na lojalnost nacionalsocijalističkom režimu u ožujku 1933. godine

dio kao umjetnik individualist: puteni zanosi, mistično sudjelovanje, neobuzdane ekstaze. Kao jedan od razloga zašto Benn nije emigrirao, Emmerich navodi njegov loš materijalni položaj kao i to da zbog nedostatka sredstava nije imao kamo otići. ${ }^{18}$

Književni suvremenici Gottfrieda Benna imali su malo razumijevanja za njegove političke postupke te su i sami pridonijeli otvorenoj polemici oko njegove ličnosti. U raspravu su se uključili lijevo orijentirani pisci poput Egona Erwina Kischa, Johannesa R. Bechera, Bertolta Brechta i drugih. Egon Erwin Kisch govori o odurnoj aristokraciji, koja zaudara iz svakog retka Bennove proze, Johannes R. Becher o pjesničkoj umišljenosti koja se kod Benna očituje u najgorim oblicima, a ljevičarski publicist Werner Hegemann zaključuje da Benn sve dublje tone u fašistički tabor i da je njegova teorija umjetnosti u skladu s Hitlerovim umom. ${ }^{19}$ Za razliku od Benna, brojni njegovi kolege književnici bili su bolje informirani o političkim zbivanjima te su prvom prilikom napustili zemlju. Među najpoznatijima je svakako već spomenuti Klaus Mann, koji je Benna okrivio za političku kratkovidnost, ali i Bertolt Brecht, za kojeg Benn kao kolaboracionist fašizma više nije bio prihvatljiva veličina. ${ }^{20}$

Bennovu relativno brzom uvidu u pogrešku u velikoj mjeri pridonijela je činjenica da za nacističke moćnike ličnost poput Benna nije bila samo nepodobna već i nepodnošljiva, jer on nije posjedovao nijednu osobinu kojom bi se uklapao u novi režim. Za voditelja Sekcije

Usp. W. EMMERICH, $n . d j$. , 89.-90.

Isto, 77.

20 Usp. Theo BUCK, „Autonomie und Gebrauchswert der Kunst: Benn und Brecht”, Text + Kritik, 23/1985., br. 44, 101. 
za pjesništvo pri Pruskoj akademiji umjetnosti Benn je imenovan 15. veljače 1933. godine. Iste godine, 8. srpnja, smijenjen je s funkcije, a na mjesto novog voditelja dolazi Hans Friedrich Blunck, odani sljedbenik nacističkog režima. Benn za vladajuću ideologiju nije bio prijetnja samo kao književnik već i kao liječnik. Iako je Hitlerova diktatura tek bila u usponu, Benn je već 1933. godine skinut s liste liječnika ovlaštenih za potpisivanje određenih liječničkih uvjerenja, a Liječnička komora Trećeg Reicha od svih je liječnika tražila popunjavanje upitnika o precima i dokaz o arijskom porijeklu. Uvidjevši svoje slijepo vjerovanje u ideje koje su se počele pretvarati u strahovitu stvarnost, kao jedino rješenje za izlaz iz političke zablude u proljeće 1935. godine Benn drži odlazak u vojsku. Dana 1. travnja stupa u službu liječnika Vrhovnog štaba u Hannoveru, a u kasnijim izjavama često će reći kako je odlaskom u vojnu službu odabrao tzv. „aristokratsku formu emigracije”. Time se jasno ogradio od politike zatrovane nacizmom, ali i od većine emigranata u inozemstvu. Povlačenje u vojsku zbog udaljavanja od književnih zbivanja u Berlinu Benna ponovno vraća u izolirani položaj, ali mu pruža i priliku za pisanje novih djela. Početkom 1936. objavljena mu je mala zbirka Gedichte (Pjesme), a potom i Ausgewählte Gedichte 1911-1936 (Izabrane pjesme 1911.-1936.) o kojima su u njemačkim dnevnim novinama objavljene desetine pozitivnih prikaza. Ali, objavljivanje zbirke poezije, koja je sadržavala i nekoliko kontroverznih pjesama iz rane faze Bennova stvaralaštva, imalo je bolne posljedice. U tjedniku pod utjecajem SS-a Das Schwarze Korps objavljen je anonimni napad na pjesnika koji je za cilj nedvojbeno imao Bennovo udaljavanje iz Wehrmachta. Samo zahvaljujući prijateljima, Benn uspijeva ostati u vojsci i osigurati svoju egzistenciju. Zbog uvreda i optužbi iznesenih u navedenom časopisu, Benn je morao napisati opravdanje da se u njegovoj zbirci radi o umjetnički značajnim pjesmama, a ne o „svinjariji” i dati časnu riječ da nije homoseksualno orijentiran. ${ }^{21}$ Tijekom vojne službe u Hannoveru nastaju i njegova nova djela, ali budući da je kritika novog režima bila sve oštrija, ne pomišlja na njihovo objavljivanje. Djela nastala u to vrijeme bit će objavljena tek nakon rata, nakon ukidanja zabrane. Čini se da je bilo potrebno nekoliko ozbiljnih udara na pjesnikovu egzistenciju kako bi uvidio „da Treće Carstvo nije bilo i njegovo carstvo". ${ }^{22}$

Sredinom 1937. godine Benn je premješten u Berlin kao sanitetski oficir te mu je ispunjena i dugogodišnja želja da napusti provincijski grad Hannover i vrati se svom starom načinu života u Berlinu. Ali, u Berlinu su nastavljeni napadi na njega. Tamošnji piščevi protivnici, nacistički simpatizeri, nazivaju ga „kulturnim boljševikom i rasnim izdajnikom". ${ }^{23}$ Iako je naredba vođe SS-a Heinricha Himmlera, koji je izdao uvjerenje o autorovu besprijekornom držanju u nacionalnom pogledu još od godine 1933., Bennu pružila zaštitu od novih napada SS-a, 18. ožujka 1938. isključen je iz Društva pjesnika Trećeg Reicha te mu je nametnuta zabrana pisanja. Međutim, izgledi da duže vrijeme neće smjeti ne samo objavljivati nego i pisati bili su, kako napominje Wolfgang Emmerich, novi oblik represije i pjesnika su duboko deprimirali. ${ }^{24}$

Početkom Drugoga svjetskog rata Benn je promaknut u glavnog liječnika poljske bolnice i bio je veoma dobro upućen u ratna zbivanja. Godine 1940. nastala je njegova studija o slučajevima suicida u vojsci, a 1941. sâm sebi je dijagnosticirao kliničku depresiju. Dijagnoza

\footnotetext{
Usp. B. HILLEBRAND, Benn, 285.

W. EMMERICH, $n . d j ., 86$.

Bruno HILLEBRAND, „Biographie Gottfried Benn”, Text + Kritik, 23/1985., br. 44, 146.

Usp. W. EMMERICH, $n . d j ., 98$.
} 


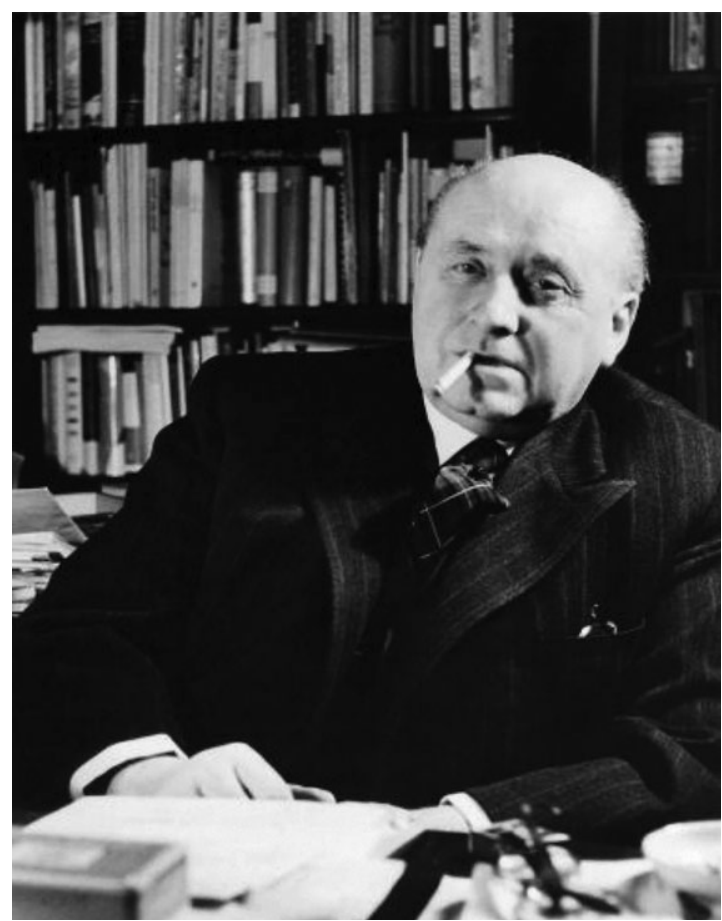

Slika 2. Gottfried Benn u svojoj radnoj sobi u studenom 1955. godine pokazuje da su prve godine rata za Benna bile iznimno teške: $s$ jedne strane zbog toga što je kao liječnik na bojišnici neposredno gledao sve ratne strahote, s druge strane zbog zabrane književnog djelovanja. Kada se vratio s rehabilitacije, Wehrmacht je već bio napao Sovjetski Savez. Tijekom 1941. i 1944. godine Bennov garnizon biva više puta premještan u Landsberg/ Warthe, gdje je Benn ukupno proveo 17 mjeseci. Jednako kao za vrijeme boravka u Hannoveru, Benn osjeća tjeskobu provincije, ali unatoč tome $\mathrm{u}$ Landsbergu nastaju neka od njegovih kasnije značajnih djela. Zbog povlačenja njemačke vojske pred Crvenom armijom Benn 1945. napušta Landsberg i vraća se u Berlin, gdje će voljeni grad zateći u kaosu i ruševinama.

Po završetku rata Bennu nije ukinuta zabrana pisanja i objavljivanja, jer se tad opet našao na crnim i sivim listama nepoželjnih autora. U pismu prijatelju Friedrichu Wilhelmu Oelzeu iz 1947. godine Benn piše kako više ne gaji nadu da će još za života imati priliku objaviti svoja djela, a za koja kaže da su to vrijedne knjige, koje će biti priznate nakon njegove smrti. ${ }^{25} \mathrm{Te}$ godine, nakon jedanaest godina šutnje, Benn počinje primati ponude izdavačkih kuća i književnih časopisa te intenzivno radi na svojim književnim djelima. Krajem godine završava zbirku Statische Gedichte (Statične pjesme) i s potajnom radošću govori o povratku na književnu scenu. Svoj pravi povratak Benn će doživjeti tek 1949., nakon „unutarnje emigracije" duže od jedanaest godina. Tada počinje objavljivati svoja nova djela u renomiranom časopisu Merkur i za njih dobiva brojne pozitivne kritike. Bennova djela godinu dana kasnije nalaze odjeka i u međunarodnim publicističkim krugovima. Prema novostečenoj popularnosti Benn je ipak ostao skeptičan. Posljednje godine pjesnikova života, zbog ponovnog kopanja po njegovoj prošlosti, ali i zbog sve lošijeg zdravstvenog stanja, obilježene su povlačenjem iz javnosti. Benn nikada nije svjesno htio biti dijelom vladajućih političkih i književnih krugova, ali se spletom okolnosti nakon 1933. godine našao u središtu njihove pažnje. Razlog zašto se svjesno povukao i uvijek nastojao ostati izvan središta Benn pojašnjava u svome Berliner Brief, Juli 1948 (Berlinsko pismo, srpanj 1948.):

(...) kada su vas kao mene proteklih petnaest godina nacisti javno nazivali svinjom, komunisti budalom, demokrati duhovnom prostitutkom, emigranti odmetnikom, religiozni patološkim nihilistom, onda vam se ne mili ponovno vraćati u takvu javnost. ${ }^{26}$

\footnotetext{
Citirano iz Bennova pisma Oelzeu od 10. siječnja 1947. prema B. HILLEBRAND, Benn, 293.

26 Gottfried BENN, „Berliner Brief, Juli 1948”, Gesammelte Werke in vier Bänden. Band IV. Autobiographische und vermischte Schriften, 280.-285. Ovdje 281.
} 
U istom pismu upućenom anonimnom izdavaču časopisa, godinu dana prije ukidanja zabrane objavljivanja, Benn rezignira zbog toga što vjerojatno neće doživjeti ponovno tiskanje vlastitih djela, a kao razlog ističe svoj univerzalni nihilistički stav. U predvečerje života Benn još jednom osjeća poriv opravdati se zašto je odabrao put u „unutarnju emigraciju” i odlučio ostati u Berlinu: „Jer to je onaj grad čiji sjaj sam volio, čiju bijedu sada domaćinski podnosim, u kojem sam dočekao drugo, treće i sada već četvrto carstvo i iz kojeg me ništa ne može nagnati na bijeg." ${ }^{27}$ Čini se da je Benn posljednjih dana života konačno pronašao mir i da se ponovnim književnim uspjehom uspio uzdići iznad svoje pogrešne procjene političkih zbivanja, o čemu svjedoči posljednje pismo prijatelju Oelzeu: „U onaj čas, budite uvjereni, neće biti straha, mi nećemo padati, mi ćemo se uzdizati (...)." 28

No, vratimo se Bennovim esejima i autobiografskim zapisima nakon početnog oduševljenja novim društvenim poretkom. Dok je u esejima iz predratnog vremena vidno prisutna rastrganost između umjetnosti i politike te piščeva slijepa perspektiva, u esejima nastalim ratnih i poratnih godina Benn jasno progovara o svojoj političkoj zabludi. Tih godina Benn piše eseje koji će biti objavljeni 1949., nakon što mu je ukinuta zabrana objavljivanja: Block II, Zimmer 66 (Blok II, soba 66, 1943./44.), Züchtung II (Uzgoj II, 1940.), Kunst und Drittes Reich (Umjetnost i Treći Reich, 1941.), Provoziertes Leben (Provocirani život, 1943.), Zum Thema Geschichte (O povijesti, objavljen posthumno 1959., nastao vjerojatno 1943.) i druge. Tako se u eseju Kunst und Drittes Reich jasno očituje Bennov u međuvremenu osviješteni stav i prezir kada govori o nacistima: „,...) imaju mozak troglodita, moral protoplazme i ponos hotelskih štakora." ${ }^{29}$ Moglo bi se reći da Benn na svoju političku zabludu i na politički program Hitlerove diktature sada već gleda s određenim sarkazmom kada zaključuje da je nacistički režim zanimanje umjetnika sveo na nivo zanatlije, čiji su nalogodavci nadzornici zatvorskih ćelija i vojnih domova te da Gestapo nadzire slikarske radionice i zabranjuje kupovinu platna i uljanih boja, a ulična straža noću pregledava štafelaje. Za totalitarnu državu odnos prema umjetnosti svodio se na suzbijanje štetočina. Kritički osvrt na Hitlerovu diktaturu Benn donosi i u eseju Zum Thema Geschichte u kojem kritizira odnos nacističke države prema umjetnicima i intelektualcima. Najprije piše o oduzimanju titule počasnog doktorata znanosti Thomasu Mannu, a zatim o mučenju u koncentracijskim logorima onih znanstvenika koji nisu htjeli sudjelovati u idiotskim teutonskim pothvatima kao i o odvođenju na prisilni rad svećenika koji su učili da je Bog iznad Hitlera. Ovdje Benn na odgovornost poziva i sve one koji su dizali ruke na pozdrav ministru Goebbelsu i mirno gledali dok su iz kuća izvodili židovsku djecu te ih bacali na kamione i zauvijek odvozili u nepoznato. ${ }^{30} \mathrm{U}$ eseju Schatten der Vergangenheit (Sjene prošlosti), objavljenom već u proljeće 1934. u rasprodanoj zbirci eseja i ponovno objavljenom 1949. godine, Benn govori o razlozima zašto je 1933. ostao u Njemačkoj. Objašnjava kako nije imao osobnih razloga da napusti Berlin. Za život je zarađivao u svojoj liječničkoj ordinaciji, a u tadašnju politiku nije bio upleten. Kako su potvrdila istraživanja brojnih kritičara, Benn i sâm kaže da nikada do kraja nije proučio partijski program te da ni prije ni poslije 1933. nije čitao nacionalsocijalistički tisak. Priznaje da je bio upućen u antisemitski program, ali da tada

\footnotetext{
Isto, 285.

28 Citirano iz Bennova posljednjeg pisma Oelzeu od 15. lipnja 1956. prema B. HILLEBRAND, Benn, 300.-301.

29 Gottfried BENN, „Kunst und Drittes Reich”, Gesammelte Werke in vier Bänden. Band I. Essays, Reden, Vorträge, 299.-322. Ovdje 318.

30 Usp. Gottfried BENN, „Zum Thema Geschichte”, Gesammelte Werke in vier Bänden. Band I. Essays, Reden, Vorträge, 371.-388. Ovdje 376.-377.
} 
nitko, pa ni on sâm, nije vjerovao u ostvarenje bolesnih rasno-političkih ideja. Dodaje i da je drhtao od straha kada su nacisti počeli prakticirati svoje rasne teoreme. ${ }^{31} \mathrm{O}$ slijepoj opčinjenosti Hitlerovom politikom te o čuđenju nad vlastitom, ali i pogreškom mnogih drugih, Benn govori u autobiografskom zapisu Block II, Zimmer 66 u kojem ocrtava iskustva ratnog liječnika na sovjetskoj fronti:

(...) pred nama je već peta godina rata ispunjena porazima i pogrešnim procjenama, očišćenim dijelovima kontinenta, razorenim ratnim brodovima, milijunima mrtvih, bombardiranim velegradovima, a masa unatoč svemu i dalje sluša prazne govore Führera i vjeruje u njih. ${ }^{32}$

Je li Gottfried Benn bio nacionalsocijalist? To je pitanje koje se i danas često postavlja. U godinama od 1933. do 1934. Benn je bio fasciniran novim političkim idejama, ali nije dovoljno poznavao njihovu pozadinu i krajnje ciljeve diktature. Pritom valja napomenuti, iako to ne ublažava Bennovu odgovornost, da su i drugi značajni autori svjetske književnosti, zagovornici esteticizma, gajili simpatije naročito prema talijanskom fašizmu. Među njima je bio američki pjesnik Ezra Pound kao i talijanski pisac, političar i utemeljitelj futurizma Filippo Tommaso Marinetti. Premda je, prema riječima Waltera Lenniga, ideologiju fašizma 1933. godine Benn slavio kao estetizaciju politike, shvatio je da su ideje totalitarne države u doba masovne histerije principijelno i nužno usmjerene protiv umjetnosti i duha. ${ }^{33}$ $\mathrm{Na}$ svu sreću, Bennovo početno slijepo vjerovanje u ideje nacionalsocijalizma iščezlo je brzo i trajno, a u pismu iz 1935., osvrćući se na 1933. godinu, Benn je prijatelju F. W. Oelzeu, kojem će do svoje smrti 1956. godine napisati preko sedamsto pisama, uputio sljedeće riječi: „Beskrajno se sramim svog pada, (...) osjećam beskrajnu tugu zbog izdaje kojom sam kanio izdati samoga sebe (...)." ${ }^{34}$ Kada Benna spominjemo kao simpatizera nacionalsocijalizma, bilježi Walter Lennig u svojoj knjizi o životu i djelu njemačkog pisca, ne smijemo zanemariti činjenicu da u njegovu opusu nema niti jedne riječi antisemitizma niti izjave, koja bi u tom smislu mogla biti pogrešno protumačena. ${ }^{35}$ Štoviše, Benn je nacionalsocijalistima okrenuo leđa čim je prozreo njihove kobne rasističke planove. Suočen sa stvarnošću nasilne vlasti ubrzo je uvidio svoju zabludu te je u djelima pokušao sačuvati duh moderne njemačke književnosti od utjecaja nacionalsocijalista.

\section{Zaključak}

Odabrani eseji i govori (Der neue Staat und die Intellektuellen, Kunst und Drittes Reich, Antwort an die literarischen Emigranten i dr.) svjedoče o Bennovom početnom oduševljenju nacionalsocijalističkom ideologijom. Benn u svojim autobiografskim djelima iznosi stavove zašto je u početku, u umjetničkom smislu, bio fasciniran novim političkim uređenjem te

\footnotetext{
31 Usp. Gottfried BENN, „Schatten der Vergangenheit”, Gesammelte Werke in vier Bänden. Band IV. Autobiographische und vermischte Schriften, (ur. Dieter Wellershoff), Stuttgart 1995., 69.-112. Ovdje 70.-71.

32 Gottfried BENN, „Block II, Zimmer 66”, Gesammelte Werke in vier Bänden. Band IV. Autobiographische und vermischte Schriften, 113.-131. Ovdje 117.-118.

33 Usp. W. LENNIG, $n . d j ., 117$.

34 Citirano iz Bennova pisma Oelzeu iz 1935. prema W. EMMERICH, $n$. dj., 92.

35 Usp. W. LENNIG, $n . d j ., 120$.
} 
opisuje događaje, koji su ga duboko potresli i zbog kojih je ubrzo uvidio strašne namjere Hitlerove diktature. Nakon što je 1933. godine na kratko vrijeme preuzeo vodstvo Sekcije za pjesništvo pri Pruskoj akademiji umjetnosti i aktivno podržao principe nacionalsocijalističke države, Benn javno nastupa propagirajući stavove u i o duhu nacionalsocijalizma. Govori o početku novoga doba, teorijama selekcije, nastanku novog - njemačkog - čovjeka, povijesnoj transformaciji države, Führeru kao stvaralačkom principu i veliča totalitarnu državu kao odraz volje naroda. Kroz godinu dana, koliko je trajala zaslijepljenost idealima nacionalsocijalizma, Benn prepoznaje svoju političku zabludu i već u ljeto 1934. godine, u pismu književnici Ini Seidel, progovara o jezovitim zločinima i tragediji Hitlerovog režima. Gottfried Benn bio je jedan od onih koji su kao „protest” protiv vladajuće ideologije odabrali povlačenje u „unutarnju emigraciju”. U radu su iznesena različita mišljenja kritičara i književnih suvremenika Gottfrieda Benna o njegovim političkim postupcima, a koja su doprinijela otvaranju polemike oko književnikove ličnosti. Jedni su opravdavali njegovo neznanje i nedovoljnu upućenost u politička zbivanja, a za druge je kao kolaboracionist $\mathrm{Hi}$ tlerove diktature bio potpuno neprihvatljiv. Dok su umjetnici i intelektualci kritizirali njegova uvjerenja, nacistički moćnici Bennu su 1933. zabranili izdavanje liječničkih uvjerenja, a 1938. godine dobio je zabranu pisanja i objavljivanja. Tijekom zabrane pisanja on stvara mnoga djela s kritičkim osvrtom na osobna stajališta i godine vladavine nacionalsocijalista. Bennovo ime će se i po završetku rata naći na listama nepoželjnih pisaca, a on ponovno počinje objavljivati tek 1949., nakon jedanaest godina stvaralačke šutnje.

\section{$\cos$}

\section{Gottfried Benn between National Socialism and INTERNAL EMIGRATION}

In 1932, the German author Gottfried Benn (1886-1956) became a member of the Prussian Academy of Arts, which came under the tutelage of the Nazi government since 1933, and Benn himself supported the ideology. A selection of his essays and speeches (Der neue Staat und die Intellektuellen, Kunst und Drittes Reich, Antwort an die literarischen Emigranten etc.) stands as evidence of Benn's early enthusiasm for National Socialism.

In his autobiographical works Benn explains why he was fascinated by the new regime and goes on to describe the events which shocked him into understanding the terrible intentions of Hitler's dictatorship. Having taken over the Poetry section of the Prussian Academy of Arts and actively supporting the principles upon which the National Socialist state was built, in his public appearances Benn expresses attitudes in the spirit of National Socialism. He speaks of the beginning of a new era, the theories of selection and the birth of a new - German - Man, the historical transformation of the country, glorifies the Führer as a creative force and the totalitarian state as an expression of the will of the people. After a year of being blinded by Nazi ideology, Benn realizes his political mistake and in the summer of 1934, in a letter to the writer Ina Seidel, speaks out about the horrifying crimes and tragedies brought about by Hitler's regime. Gottfried Benn went on to join those who chose "internal emigration" as a form of "protest" against the ruling ideology.

This paper brings various opinions by literary critics and Gottfried Benn's literary contemporaries about his political activity, opinions which contributed to the discussions of the writer's person. While some tried justify his ignorance and lack of awareness in political matters, others rejected him completely as a collaborationist. While artists and intellectuals criticized his attitudes, the $\mathrm{Na}$ - 
zi authorities forbade Benn to practice medicine in 1933, and in 1938 banned him from writing and publishing. During this ban, Benn wrote numerous works critical of his own personal attitudes and the years of Nazi rule. Benn's name would continue to be listed amongst the undesireable even after the war and he himself did not begin publishing again until 1949, after eleven years of artistic silence.

Keywords: Gottfried Benn, literature of the "internal emigration”, literature in the Third Reich, World War II

\section{$\cos$}

\section{Literatura}

Barbara BAUMANN - Birgitta OBERLE, Deutsche Literatur in Epochen, München 1995.

Gottfried BENN, „Antwort an die literarischen Emigranten”, Gesammelte Werke in vier Bänden. Band IV. Autobiographische und vermischte Schriften, (ur. Dieter Wellershoff), Stuttgart 1995. 239.-248.

Gottfried BENN, „Berliner Brief, Juli 1948”, Gesammelte Werke in vier Bänden. Band IV. Autobiographische und vermischte Schriften, (ur. Dieter Wellershoff), Stuttgart 1995., 280.-285.

Gottfried BENN, „Block II, Zimmer 66”, Gesammelte Werke in vier Bänden. Band IV. Autobiographische und vermischte Schriften, (ur. Dieter Wellershoff), Stuttgart 1995., 113.-131.

Gottfried BENN, „Der neue Staat und die Intellektuellen”, Gesammelte Werke in vier Bänden. Band I. Essays, Reden, Vorträge, (ur. Dieter Wellershoff), Stuttgart 1993., 440.-449.

Gottfried BENN, „Kunst und Drittes Reich”, Gesammelte Werke in vier Bänden. Band I. Essays, Reden, Vorträge, (ur. Dieter Wellershoff), Stuttgart 1993., 299.-322.

Gottfried BENN, „Schatten der Vergangenheit”, Gesammelte Werke in vier Bänden. Band IV. Autobiographische und vermischte Schriften, (ur. Dieter Wellershoff), Stuttgart 1995., 69.-112.

Gottfried BENN, „Züchtung I”, Gesammelte Werke in vier Bänden. Band I. Essays, Reden, Vorträge, (ur. Dieter Wellershoff), Stuttgart 1993., 214.-222.

Gottfried BENN, „Zum Thema Geschichte”, Gesammelte Werke in vier Bänden. Band I. Essays, Reden, Vorträge, (ur. Dieter Wellershoff), Stuttgart 1993., 371.-388.

Peter J. BRENNER, Neue deutsche Literaturgeschichte. Vom „Ackermann” zu Günter Grass, Tübingen 2004.

Theo BUCK, „Autonomie und Gebrauchswert der Kunst: Benn und Brecht”, Text + Kritik, 23/1985., br. 44, 99.-117.

Wolfgang EMMERICH, Gottfried Benn, Reinbek bei Hamburg 2006.

Bruno HILLEBRAND, Benn, Frankfurt/Main 1986.

Bruno HILLEBRAND, „Biographie Gottfried Benn”, Text + Kritik, 23/1985., br. 44, 136.-155.

Walter LENNIG, Gottfried Benn mit Selbstzeugnissen und Bilddokumenten, Reinbek bei Hamburg 1994.

Paul RIEGEL - Wolfgang VAN RINSUM, Deutsche Literaturgeschichte. Band X. Drittes Reich und Exil 1933-1945, München 2000.

Bernhard ZIMMERMANN, „NS-Literatur, Exil und Innere Emigration”, Deutsche Literaturgeschichte. 20. Jahrhundert, (ur. Georg Bollenbeck, Bernhard Zimmermann, Otto F. Riewoldt i Knut Hickethier), Düsseldorf 1984., 41.-71. 